\title{
Chondroitin Sulfate Proteoglycan 4 and Its Potential As an Antibody Immunotherapy Target across Different Tumor Types
}

\author{
Kristina M. Ilieva ${ }^{1,2}$, Anthony Cheung ${ }^{1,2}$, Silvia Mele ${ }^{1}$, Giulia Chiaruttini ${ }^{1}$, Silvia Crescioli ${ }^{1}$, \\ Merope Griffin', Mano Nakamura',3, James F. Spicer', Sophia Tsoka ${ }^{3}$, Katie E. Lacy', \\ Andrew N. J. Tutt ${ }^{2,5}$, and Sophia N. Karagiannis ${ }^{1,2 *}$
}

'St. John's Institute of Dermatology, School of Basic \& Medical Biosciences, King's College London \& NIHR Biomedical Research Centre at Guy's and St. Thomas' Hospitals and King's College London, Guy's Hospital, London, United Kingdom,

OPEN ACCESS

Edited by:

Jose A. Garcia-Sanz,

Consejo Superior de Investigaciones Cientificas (CSIC), Spain

Reviewed by: Eric Vivier, UMR7280 Centre d'immunologie de Marseille-Luminy (CIML), France

Pierre Busson, Institut Gustave Roussy, France

*Correspondence: Sophia N. Karagiannis sophia.karagiannis@kcl.ac.uk

Specialty section: This article was submitted to Cancer Immunity and Immunotherapy, a section of the journal

Frontiers in Immunology

Received: 30 August 2017 Accepted: 14 December 2017 Published: 10 January 2018

Citation:

llieva KM, Cheung A, Mele S, Chiaruttini G, Crescioli S, Griffin M, Nakamura M, Spicer JF, Tsoka S,

Lacy KE, Tutt ANJ and Karagiannis SN (2018) Chondroitin Sulfate Proteoglycan 4 and lts

Potential As an Antibody Immunotherapy Target across Different Tumor Types.

Front. Immunol. 8:1911. doi: 10.3389/fimmu.2017.01911 ${ }^{2}$ Breast Cancer Now Research Unit, School of Cancer and Pharmaceutical Sciences, King's College London, Guy's Cancer Centre, London, United Kingdom, ${ }^{3}$ Department of Informatics, Faculty of Natural and Mathematical Sciences, King's College London, London, United Kingdom, ${ }^{4}$ School of Cancer and Pharmaceutical Sciences, King's College London, Guy's Cancer Centre, London, United Kingdom, ${ }^{5}$ Breast Cancer Now Toby Robins Research Centre, Institute of Cancer Research, London, United Kingdom

Overexpression of the chondroitin sulfate proteoglycan 4 (CSPG4) has been associated with the pathology of multiple types of such as melanoma, breast cancer, squamous cell carcinoma, mesothelioma, neuroblastoma, adult and pediatric sarcomas, and some hematological cancers. CSPG4 has been reported to exhibit a role in the growth and survival as well as in the spreading and metastasis of tumor cells. CSPG4 is overexpressed in several malignant diseases, while it is thought to have restricted and low expression in normal tissues. Thus, CSPG4 has become the target of numerous anticancer treatment approaches, including monoclonal antibody-based therapies. This study reviews key potential anti-CSPG4 antibody and immune-based therapies and examines their direct antiproliferative/metastatic and immune activating mechanisms of action.

Keywords: CSPG4, MCSP, HMW-MAA, NG2, melanoma, triple-negative breast cancer, immunotherapy, antibodies

\section{INTRODUCTION}

Recent advances in the field of cancer immunotherapy, involving specific targeting modalities like monoclonal antibodies or chimeric antigen receptor (CAR) T cell therapies, depend on the identification of appropriate surface antigens. The search for appropriate targets is especially important for certain malignancies such as triple-negative breast cancer (TNBC), which lack expression of the human epidermal growth factor receptor 2 (HER2/neu), estrogen or progesterone receptors, thus rendering them insensitive to available targeted therapies.

Chondroitin sulfate proteoglycan 4 (CSPG4) is a highly glycosylated transmembrane protein, and a member of the chondroitin sulfate group of glycosaminoglycans (GAGs). CSPG4, also referred to as melanoma-associated chondroitin sulfate proteoglycan (MCSP), high-molecular-weight melanoma-associated antigen (HMW-MAA), or neuron-glial antigen 2 (NG2), was first associated with malignant melanoma and subsequently implicated in the pathology of other solid tumors of 
different origins, as well as of hematological cancers (1). It has been investigated as a potential immunotherapy target due to its restricted/low distribution in normal tissues and overexpression in certain tumors at different disease stages, and based on evidence for multiple roles in supporting tumor growth and dissemination. Together, long-emerging studies point to CSPG4 as a promising target for cancer therapies, including immunotherapies with monoclonal antibodies. In this review, we summarize reported functions of CSPG4 in cancer and we examine the development of ongoing immunotherapy strategies, most notably monoclonal antibodies that target CSPG4.

\section{CSPG4 NORMAL TISSUE DISTRIBUTION, STRUCTURE, AND PHYSIOLOGICAL FUNCTIONS}

Chondroitin sulfate proteoglycan 4 is heterogeneously expressed on normal tissues such as mesenchymal stromal cells-adult progenitor cells, which have been suggested to lose its expression during terminal differentiation (2). Early immunofluorescence/ immunohistochemisry data on the distribution of CSPG4 in normal tissues suggest it is expressed in nevi, epidermis and hair follicles but not detected in brain, thyroid, thymus, lung, liver, ureter, testis, spleen, ovary, or peripheral nerves (3). In another early study, immunohistochemical analysis of fetal and adult human tissues suggest CSPG4 distribution in the adrenal cortex, liver, choroid and small intestine in the fetus and in adult peripheral nerves, liver, salivary glands, bladder, lung bronchial glands and sebaceous glands (4). In more recent studies, expression of CSPG4 and its rat ortholog has been reported at low or moderate levels on neuronal glial cells, arteriolar pericytes, smooth muscle cells, macrophages, melanocytes, articular chondrocytes, and others (5-11). At the RNA level, CSPG4 expression has been recently reported in skin, trachea, veins, lung, heart, muscle, diaphragm, adipose tissue, uterus, prostate, thymus, spleen, bone marrow, and gastrointestinal tissue, but importantly at 6.6 times lower levels than in tumors (12).

Its physiological functions are not completely understood and multiple studies report specific roles in different tissues throughout development. In placenta formation, the expression of CSPG4 on extravillous trophoblasts has been implicated in their differentiation and migration (13). CSPG4 is also proclaimed to be involved in angiogenesis and vascularization. Using murine in vivo models, NG2 was shown to induce de novo vascularization of otherwise the avascular corneal tissue, suggesting an important role in angiogenesis (14). Further reports suggest the involvement of CSPG4 in glial and oligodendrocyte formation and neuronal network regulation, epithelial keratinocyte replenishment, and epidermal stem cell positioning and homeostasis $(15,16)$.

Although a full understanding of the physiological roles of CSPG4 is still required, all reports suggest it is ubiquitously involved in multiple tissue development and homeostasis processes, and its roles may be differentially modulated based on the nature of the local tissue microenvironment (17). The regulation of CSPG4 expression is reported to be strongly affected by inflammatory cytokines such as TNF- $\alpha$, interleukin (IL)- $1 \alpha$, IFN- $\gamma$, and
TGF- $\beta$ and hypoxia-induced mechanisms involving hypoxiainducible factors. Furthermore, CSPG4 expression was described to depend on epigenetic pathways, certain transcription factors and microRNAs (see Ampofo et al. for review).

Its functional versatility could be explained by its protein scaffold structural characteristics (Figure 1). CSPG4 is a type I single pass transmembrane protein which exists as a core glycoprotein and chondroitin sulfate-decorated proteoglycan (18). Studies with the rat ortholog state CSPG4 consists of a large extracellular portion, a transmembrane domain and a short intracellular portion (19). The extracellular portion comprises three distinct domains. Located furthest from the membrane, D1 is composed of two laminin G-type subdomains and is abundant in disulfide bonds, important for the stability of tertiary structure. This domain is potentially involved in the interactions with the extracellular matrix (20). The middle domain, D2, comprises 15 CSPG4 specific repeats containing several potential glycosylation and chondroitin sulfate binding sites. The CS decoration may confer different attributes, including interaction with integrins and metalloprotease activation $(21,22)$. It is presently unclear whether CSPG4 is characterized with different glycosylation/ glycanation patterns in normal or cancerous tissues. The D2 domain has also been proposed to directly bind collagens $(23,24)$. Although CSPG4 has no reported enzymatic functions, murine ortholog studies suggest it may bind growth factors and present them to receptor tyrosine kinases (RTKs), thus acting as a RTK coreceptor $(25,26)$.

Domain D3 is the one proximal to the cellular membrane, and contains putative protease cleavage sites as well as carbohydrate decoration, suggesting potential interactions with lectins and integrins $(27,28)$. Proteolytic cleavage may also allow ectodomain shedding. In support, levels of soluble CSPG4 have been reported in the sera of healthy individuals and patients with melanoma (29). The presence of soluble CSPG4 within circulation has been proposed as a potential diagnostic biomarker to aid melanoma detection and classification at the vertical growth phase (29). Moreover, CSPG4 may undergo endocytic recycling mediated by the endocytic receptor Stonin 1 (30). Thus, endocytosis and ectodomain shedding of CSPG4 may point to different mechanisms involved in the turnover of membrane-bound protein.

The intracellular portion of CSPG4 is characterized by the presence of a threonine- and a proline-rich motif and a PDZ [postsynaptic density protein 95 (PSD-95)_Drosophila disc large tumor suppressor (Dlg1) - Zona occludens 1 (ZO-1)] domain $(31,32)$. The threonine motifs serve as kinase phosphoacceptor sites for protein kinase $\mathrm{C} \alpha(\mathrm{PKC} \alpha)$ and extracellular signalregulated kinase $1 / 2(\mathrm{ERK} 1 / 2)(33,34)$. The proline-rich domain and the PDZ domain most likely function as protein scaffolds for other intracellular proteins (31). The structural characteristics of CSPG4 may confer possible functions as a signaling mediator molecule, connecting the extracellular matrix (ECM) with two main intracellular signaling cascades-the integrin-focal adhesion kinase (FAK) axis through integrin interactions and the mitogen-activated protein kinase (MAPK) pathway through activation of RTKs and ERK1/2 $(33,35,36)$. These may bestow functional attributes that could encompass promotion of cellular survival, proliferation, and motility. Importantly, studies with 


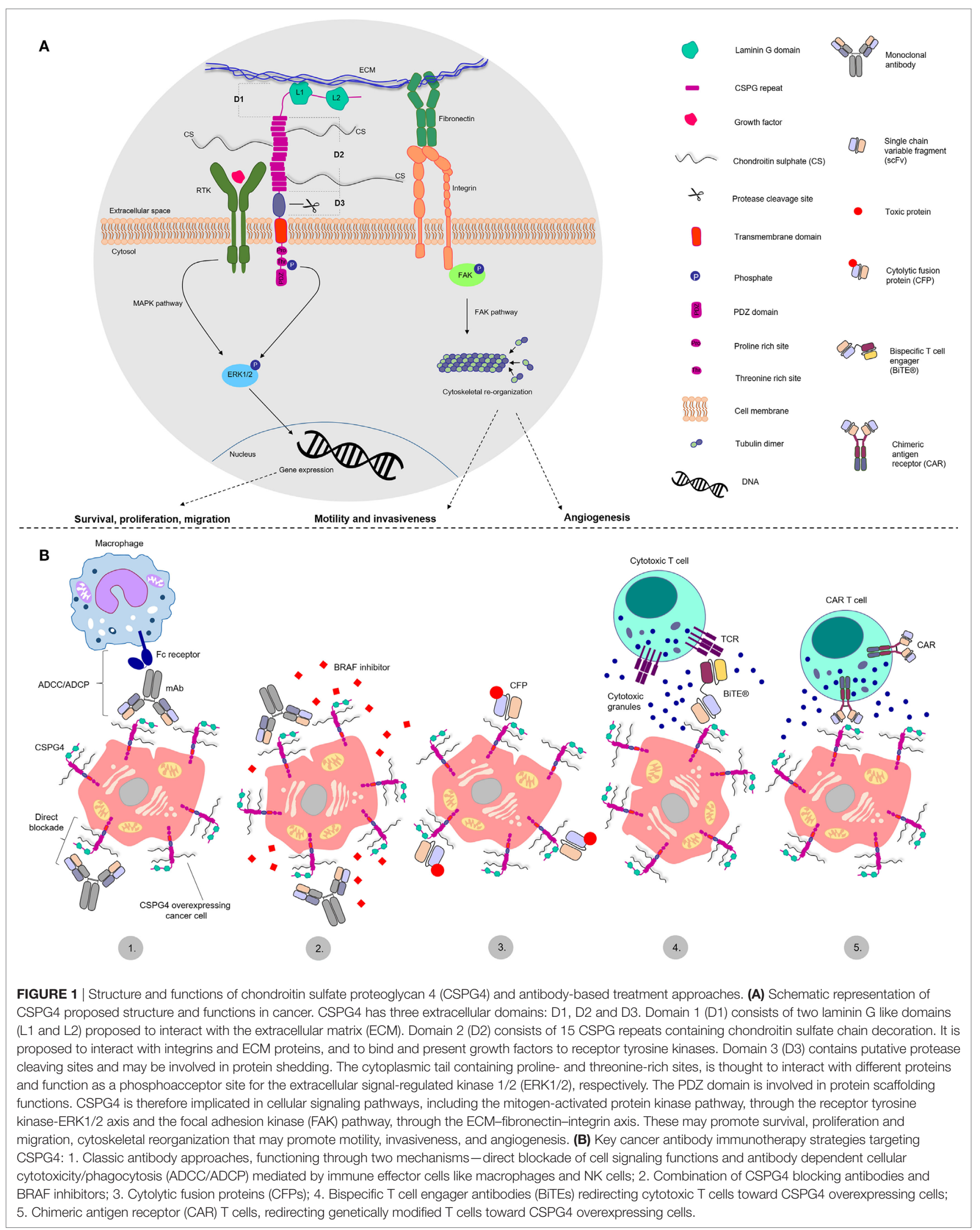


NG2 knockout mice suggest that deletion of this antigen is not lethal (37).

Therefore, research studies into CSPG4 point to stem cell origin, multiple functions in tissue development, together with regulation of expression by inflammation, hypoxia, decreased methylation mechanisms, as well as specific protein scaffolding structure and reported roles in cell signaling. These features may also translate to contributions in cancer pathology in several tumor types.

\section{CSPG4 EXPRESSION AND PUTATIVE PATHOLOGICAL FUNCTIONS IN CANCER}

Early reports associated overexpression of CSPG4 with malignant melanomas, and more recently its enhanced expression has been identified in other cancer types. Despite these developments, the exact involvement of CSPG4 in the etiology of cancer is widely unknown.

It remains unclear whether CSPG4 has a role in tumor initiation or its expression only accumulates in tumors as a secondary tumor-associated event. Overexpression of CSPG4 has not been reported to be a result of genetic aberrations such as gene amplifications or chromosome translocation, suggesting CSPG4 may not be a primary driver in the onset of cancer. Even though its expression is not connected to the onset of epithelial tumors or hematological cancers, it has been linked to the putative mesenchymal stem cell origin of sarcomas and the epithelial-mesenchymal transition in melanoma, thought to be important for malignant transformation (36, 38-40). Several reports point toward potential roles in cancer growth and dissemination. Expression of the CSPG4 rodent homolog has been shown to localize in the invasive front of the filopodia of oligodendrocytes, suggesting involvement in mediating tumor cell motility and cancer dissemination $(38,41)$. In support, immunohistochemistry data evaluating CSPG4 expression in human melanoma claim higher levels in metastatic lesions than in primary tumors, and CSPG4 mRNA expression was reported to be predictive of metastasis formation in soft tissue sarcoma patients $(6,42)$.

Furthermore, CSPG4 is believed to contribute to cancer growth and progression through promotion of angiogenesis. Using cell line and patient derived glioblastoma xenografts in nude mice, Wang et al. reported that NG2 RNA interference in vivo decreased tumor volume and vasculature (43). In addition, a retrospective study focused on germline polymorphisms related to the function of pericytes in colorectal cancer, identified a CSPG4 polymorphism to be predictive of lower progression-free survival in patients treated with the monoclonal antibody ( $\mathrm{mAb}$ ) bevacizumab-specific for the vascular endothelial growth factor (44). More evidence is required to clarify the exact mechanism through which CSPG4 promotes angiogenesis in cancer.

Disparate reports therefore point to potential contributions of CSPG4 in cancer growth, vascularization, dissemination, and metastasis (Figure 1). These may provide opportunities for therapeutic interventions targeting CSPG4 and multiple cancerassociated pathways this molecule may be involved in.

\section{Expression in Neuroectodermal Cancers Malignant Melanoma}

Among the neuroectodermal tumors, malignant melanoma is the most thoroughly characterized in terms of CSPG4 expression and functions (36). CSPG4 is the only well characterized cell surface melanoma-associated antigen and it has been examined as a potential target employing different therapeutic approaches. It is expressed in over $70 \%$ of melanomas, and its expression has been detected throughout different disease stages.

Multiple studies demonstrate the importance of a functional full length CSPG4 for the survival, growth, and motility of melanoma tumor cells in vitro and tumor formation in vivo. CSPG4 contributes to enhanced activation of the integrin-FAK pathway through interaction with ECM components, which leads to integrin clustering and subsequent downstream signaling, cytoskeletal reorganization and increased motility and invasiveness (14, 21, $27,33,35)$. On the other hand, CSPG4 facilitates the MAPK pathway through activation of ERK1 and ERK2. ERK1 and 2 can then regulate the microphthalmia-associated transcription factor, which then alters the levels of vital proteins-increasing the expression of fibronectin, but also repressing the expression of E-cadherin, both of which have been shown to be associated with metastasis (45-49).

Since a big proportion of melanomas feature constitutively active MAPK pathway due to mutations in the gene encoding the serine/threonine-protein kinase, BRAF, several groups have investigated the effect of CSPG4 in BRAF mutant melanoma in vitro. Full length CSPG4 is required for maximal activation of ERK1/2, and siRNA inhibition of CSPG4 leads to a reduction in ERK signaling (50). Importantly, in vitro studies report that specific small molecule inhibitors for mutant BRAF can synergize with the 225.28 anti-CSPG $4 \mathrm{mAb}$ in inhibiting cell growth and proliferation (51). On the other hand, ERK1/2 signaling blockade leads to reduced CSPG4-dependent cancer cell motility (50). These reports suggest that alongside constitutive activation of BRAF, CSPG4 may additionally promote MAPK pathway activation.

\section{Glioma}

Expression of CSPG4 is found in subsets of normal glial cells in developing and adult central nervous system (see Dimou and Gallo for a review) (52). Although less well examined than melanoma, CSPG4 expression has also been associated with gliomas that originate from astrocytes, such as glioblastoma multiforme (GBM) (53-55). In a study analyzing mRNA expression data sourced from The Cancer Genome Atlas, CSPG4 mRNA levels were reported to be elevated compared to normal tissue controls (54). As in melanoma, functions of CSPG4 in glioblastoma are believed to be related to malignant progression through facilitating tumor cell interactions with collagen and promoting angiogenesis $(56,57)$. Interestingly, as reviewed by Ampofo et al., the expression levels of both CSPG4 and the platelet-derived growth factor receptor alpha (PDGFR- $\alpha$ ) in glioma are downregulated by micro RNA miR192-2 (17). Moreover, CSPG4 and PDGFR- $\alpha$ have been reported to interact and enhance cell proliferation upon PDGF stimulation. Therefore, miR129-2 has been proposed by Ampofo et al., to have therapeutic potential in glioma. CSPG4 
has also been associated with pediatric brain tumors such as medulloblastoma (58-60).

\section{Expression in Epithelial Cancers}

\section{Breast Cancer}

Another cancer type of epithelial origin, whose associations with CSPG4 have attracted a surge of interest, is breast cancer. Expression of CSPG4 in triple-negative breast cancer (TNBC) in particular is of special value, since this subtype represents an area of unmet need for novel targeted therapies. TNBCs, comprising $15 \%$ of all breast cancers, lack expression of the estrogen, progesterone and the HER2. Their triple-negative status makes them insensitive to the current hormone and HER2 targeted therapies. TNBCs are more aggressive with worse prognosis compared with other breast cancer types with no targeted therapies available, and therefore, novel targets and treatment options are urgently required.

Chondroitin sulfate proteoglycan 4 expression was described in TNBC primary lesions and metastatic tumor cells from pleural infusions, including cancer stem cells (61). Although CSPG4 expression does not appear to be expressed exclusively by basal breast cancers including TNBCs, its expression may be associated with poor prognosis and relapse in breast cancers (62). Findings to-date indicate a link between the expressions of carbohydrate sulfotransferase-11 (encoded by CHST11) which is involved in decorating CSPG4 with chondroitin sulfate and the metastatic behavior of triple-negative breast cancer cells (63). Reportedly, CHST11 is overexpressed in aggressive breast cancers and facilitates the interaction between p-selectin and CSPG4. These observations are in line with the proposed role of CSPG4 as a mediator between the ECM and intracellular signaling pathways and a metastatic driver, P-selectin. The latter is thought to allow cancer cells to resist the immune response, and to support binding to endothelial cells, and thus hematogenous spread (64). Further research is required to elucidate the CSPG4 pathological contributions to breast cancer formation and progression.

\section{Head and Neck Cancers}

Head and neck squamous-cell carcinomas (HNSCC) normally have a poor prognosis, with a 5-year survival rate of around 40-50\%. Warta et al. recently reported CSPG4 to be significantly overexpressed in HNSCC cells (65). Furthermore, high expression in patient lesions was found to correlate with poorer prognosis compared with low expression of CSPG4 (65). The study noted that few biomarkers are currently available to predict survival in HNSCC, and that CSPG4 could in future serve as a prognostic indicator.

\section{Expression in Mesenchymal Cancers}

A recent study using murine sarcoma models demonstrated that both malignant bone and soft tissue sarcomas, as well as benign desmoid tumors could originate from CSPG4-expressing pericyte cells (66). Nevertheless, the authors did not investigate the specific implications of CSPG4 expression in the tumor formation process. Another potential mechanism described by Cattaruzza et al. suggests an interplay between CSPG4 and type VI collagen in the progression of soft-tissue sarcoma (67). The same study reports upregulation of both CSPG4 and collagen type VI in soft-tissue sarcoma lesions and suggests that the combination can predict metastasis and poor clinical prognosis. However, the role of CSPG4 in mesenchymal tumors is yet to be revealed.

\section{Expression in Hematological Cancers}

Chondroitin sulfate proteoglycan 4 expression has also been reported in acute myeloid leukemia and acute lymphoblastic leukemia (ALL), while it is not expressed on normal lymphocytes, granulocytes or hematopoietic progenitor cells (68-71). Remarkably, for both ALL and AML, CSPG4 expression strongly correlated with the 11q23 gene rearrangement of the KMT2A gene encoding the lysine methyltransferase $2 \mathrm{~A}$. The mechanisms behind this correlation are still unknown. Nicolosi et al., shared an unpublished observation that a potential function of CSPG4 in leukemic malignancies could be induction of drug resistance, based on CSPG4 in vitro knock-in experiments in mixed lineage leukemia gene bearing cells, resulting in increased drug transporter expression (38).

\section{CSPG4 AND CROSS-TALK WITH THE IMMUNE SYSTEM}

Several studies have investigated the interactions between the chondroitin sulfate chains of proteoglycans or their degradation products and components of the immune system.

It has been reported that CS could stimulate monocytes to secrete IL-1 $\beta$ and to induce B cell proliferation in vitro (72). The effect of CS on B cell proliferation was corroborated by Aoyama et al., who demonstrated that CS could enhance murine B cell proliferation in vitro through $\mathrm{PKC}$ translocation and activation of protein kinase B (PKB, Akt) kinase (73). A role of CS in the maturation of dendritic cells was suggested with human monocyte-derived dendritic cells cultured in vitro in the presence of CS, hyaluronic acid, components of the ECM and human granulocyte-macrophage colony-stimulating factor (GM-CSF). CS-stimulated cells could differentiate faster than when cultured with GM-CSF and IL-4 (74). Another study utilizing splenocytes from ovalbumin (OVA)-immunized mice cultured ex vivo, showed that CS addition to culture stimulated secretion of Th1-type cytokines including IFN- $\gamma$, IL-2, and IL-12 and suppressed the secretion of Th2-type cytokines (IL-5 and IL-10) (75). Moreover, injection of $\mathrm{BALB} / \mathrm{c}$ mice with CS and other glycosaminoglycans (GAGs) was shown to induce autoimmune conditions like rheumatoid arthritis through recruitment of $\mathrm{CD}^{+} \mathrm{T}$ cells (76). In addition, treatment of murine NK cells with chondroitinase or a proteoglycan biosynthesis inhibitor resulted in substantial decrease in IFN- $\gamma$ secretion through interaction with murine IL-12. On the other hand, CSPG low-molecular weight disaccharide fragments could control the inflammatory response in a mouse model of autoimmune encephalitis, in a rat model of inflammation-mediated neuropathology of the eye, and in a delayed-type hypersensitivity model in Balb/c mice through reduced migration and activation of inflammatory T cells (77).

With regards to the role of chondroitin sulfate proteoglycans (CSPGs), an early study reported these located inside the granules 
of human NK cells and their exocytosis during NK cell-mediated cytotoxicity of tumor cells (78). Furthermore, a study of primary cultured human macrophages, showed secreted CSPGs as metabolic products of macrophages and increased secreted CSPG4 following lipopolysaccharide (79) stimulation (80).

A more recent immune monitoring study identified that both healthy individuals and melanoma patients have circulating CSPG4-reactive $\mathrm{CD} 4^{+} \mathrm{T}$ cells. The study did not report a significant correlation between the T cell responses against a HLA-DR presented CSPG4 peptide, quantified through IFN- $\gamma$ production, and the tumor burden of patients. The authors showed that a smaller proportion of the melanoma patients (11 out of 42) compared to healthy volunteers (11 out of 13) exhibited $\mathrm{T}$ cell reactivity to CSPG4 (81). Other in vivo studies demonstrated that LPS induced the expression of the murine CSPG4 ortholog by rat microglia cells. Further in vitro experiments showed that NG2 RNA silencing of LPS-treated microglia blocked the mRNA expression of nitric oxide synthase (Yajima et al.), and of proinflammatory cytokines including IL- $1 \beta$ and tumor necrosis factor $\alpha$ (TNF- $\alpha$ ), but not of chemokines like monocyte chemoattractant protein 1 and stromal cell-derived factor $1 \alpha(\mathrm{SDF}-1 \alpha)$. Importantly, this study demonstrated that NG2 is not only expressed upon stimulation of the microglia, but it likely has a role in regulating expression of pro-inflammatory cytokines (82).

In summary, chondroitin sulfate proteoglycans (CSPGs), CS carbohydrate chains, as well as small molecular weight CS degradation products and CSPG4, each appear to influence the activation, maturation, proliferation and migration of different immune cell subsets. The definitive roles for CSPG4 in the immunology of cancer are however still widely unexplored. More research is required to clarify whether the interactions between CSPG4, its amino acid or carbohydrate moieties and different components of the immune system could be exploited to enhance patient response to CSPG4 targeted immunotherapy or to be counteracted to avoid potential negative immunomodulatory functions.

\section{CSPG4 AS A TARGET FOR ANTIBODY THERAPIES IN CANCER}

Since CSPG4 is found to be overexpressed in a number of malignancies and based on its low and restricted distribution in normal tissues, alongside emerging evidence for crucial roles in cancer growth and dissemination, much research has focused on the development of different therapeutic approaches, including monoclonal antibodies. Some of these antibody-based strategies focused on CSPG4 are discussed below.

\section{Classic mAb Approaches}

Published studies describe a limited number of $\mathrm{mAb}$ clones recognizing CSPG4, the most commonly cited of which is a murine clone, 225.28. One of the earliest efficacy studies reports the antitumor efficacy of the murine 225.28 conjugated to methotrexate in nude mice bearing human melanoma xenografts (83). Even though conjugated $\mathrm{mAb}$ had superior efficacy to methotrexate alone, the efficacy of the $\mathrm{mAb}$ alone was not investigated. Melanoma tumor-bearing SCID mice treated with the murine mAb 225.28 bore smaller tumors compared with controls, and treatments were associated with modulation of various tumor suppressor-genes and genes involved in cancer metastasis (84). Besides melanoma, this murine $\mathrm{mAb}$ was also reported to inhibit the proliferation, adhesion and migration of TNBC cells, as well as to downregulate tumor-promoting signaling pathways in vitro. Moreover, the murine $\mathrm{mAb}$ was demonstrated to reduce tumor growth in two human TNBC cell line-derived lung metastasis models in SCID mice, and to decrease tumor angiogenesis and tumor recurrence after surgical removal in an orthotopic human TNBC cell line xenograft model in SCID mice (61). The murine antibody clone 225.28 was later also demonstrated to restrict tumor growth synergistically in combination with BRAF inhibitors in vitro (51). The anticancer potential of $\mathrm{mAb} 225.28$ was tested against $11 \mathrm{q} 23$ ALL cells (71). The mAb on its own showed no direct effects on proliferation inhibition in ALL cells in vitro, but it increased the efficacy of the chemotherapy agent Cytarabine. The mAb 225.28 also showed some tumor growth restriction efficacy in a subcutaneous ALL model in SCID mice. One of the first studies reporting an antibody engineered with a human $\mathrm{Fc}$ region, was of a chimeric version of the mouse $\mathrm{mAb} 225.28$. The study showed that this $\mathrm{mAb}$ could mediate antibody-dependent cellular phagocytosis (ADCP) by human monocytes in vitro and could restrict tumor growth in vivo in a melanoma NOD-SCIDGamma (NSG) mouse model engrafted with human immune cells (85) Interestingly, anti-CSPG4 IgG4 was demonstrated to not only lack tumor inhibition properties in vivo, but to also impair the efficacy of its IgG1 analog when administered in combination. This finding highlights the importance of choosing appropriate $\mathrm{Fc}$ domain and antibody isotype when designing therapeutic mAbs. Moreover, the original murine anti-CSPG4 clone 225.28 has been reported to exhibit direct cancer cell proliferation inhibition properties. In this context, the data reported by Karagiannis et al. opens different avenues for discussion and future investigation, concerning the effect of chimerizing or humanizing mAbs on their direct blockade properties, as well as the magnitude of the immunologically induced anticancer effects engendered by $\mathrm{mAb}$ immunotherapy.

Chondroitin sulfate proteoglycan 4 has also been targeted in other malignant indications using different antibody clones. The murine $\mathrm{mAb}$ clone TP41.2 was used in malignant mesothelioma (86). TP41.2 showed in vitro antitumor effects by reducing cancer cell proliferation, adhesion, motility, migration and invasion. The antibody also reduced tumor growth in vivo and prolonged the survival of mesothelioma-bearing SCID mice. In a different study by Wang et al. the authors utilize a single-chain variable fragments (scFv) fused to a human IgG1 Fc portion-scFv-FcC21 and demonstrated growth and migration inhibition of a TNBC cell line in vitro, as well as reduction of lung metastasis in a melanoma cell line model in SCID mice in vivo (87). The scFc-FcC21 antibody was shown not to be able to induce antibody-dependent cellular cytotoxicity or phagocytosis in vitro. Furthermore, an antimouse CSPG4/NG2 antibody clone 9.2.27 was conjugated to polyethylene glycol to increase its affinity for rat Fc $\gamma$ RIII on rat NK cells, and was used in combination with adoptive NK cells in glioblastoma engrafted athymic rats. The combination of 
adoptive NK cell transfer and PEGylated mAb 9.2.27 could restrict tumor growth in vivo (88). Curiously, the authors accounted the therapeutic efficacy to macrophages recruited to the tumor, whose clodronate-mediated depletion abolished the antitumor effects of the mAb. The authors suggested that the adoptively transferred $\mathrm{NK}$ cell plus mAb treatment might be responsible for re-educating tumor-infiltrating macrophages to render antitumor functions, however, the exact mechanism remains unknown. Interestingly, the antigenic determinants of the monoclonal antibodies, described in the above section, have been suggested to recognize the CSPG4 core protein independently of the presence of chondroitin sulphate $(89,90)$. It has also been proposed that removal of the CS decoration from the core CSPG4 protein would not affect the reactivity towards CSPG4 of any of the murine clones, mentioned above. Nevertheless, these observations require further confirmation (89).

Even though certain anti-CSPG4 antibody clones showed promise for therapeutic application in different cancer types and in a number of in vitro and in vivo models, most of published studies were performed using antibodies with mouse Fc regions. With some encouraging findings against CSPG4-expressing tumors, the potential of anti-CSPG4 antibodies against cancer would benefit from further in-depth research using novel constructs including those engineered with human Fc regions.

\section{Anti-idiotypic Antibodies}

Early strategies targeting CSPG4 utilized the development of antiidiotypic antibodies (anti-id), which target the binding sites of other anti-CSPG4 antibodies, essentially mimicking the tumor antigen's binding site on the antibody, and thus aiming to serve as immunogens or vaccines $(91,92)$. A clinical study reported increased survival and metastasis regression in patients with melanoma who developed anti-CSPG4 antibodies following administration of the anti-idiotypic mAb MK2-23 (93). Despite the promising clinical results, MK2-23 never reached clinical application as a therapy due to standardization issues and safety concerns linked to its administration together with the adjuvant Bacille CalmetteGuerin (BCG), deemed necessary for triggering effective adaptive immune responses (94). Further approaches to overcome those issues included fusing MK2-23 to human IL-2 (94) or utilizing DNA vaccines encoding MK2-23 scFv (95). In a phase I clinical trial, another anti-idiotypic antibody, MF11-30, induced complete remission in one advanced melanoma patient as well as conferred minor survival benefits in three other patients with advanced melanoma whilst no toxicities were reported as a part of Ref. (96).

Another approach concerns vaccine approaches, such as mimotope vaccination studies utilizing conformational CSPG4 epitopes recognized by the 763.74 or the 225.28 S anti-CSPG 4 $\mathrm{mAb}$ clones. Such strategies have been studied and reported induction of CSPG4-specific antibodies in mimotope-vaccinated animals, as well as promising antimelanoma activity of these antibodies in vitro through direct proliferation inhibition or in murine effector cell ADCC assays (97-99).

Even though anti-id antibody strategies or mimotope vaccines are currently not in the spotlight, these early studies indicate that CSPG4 may be a promising target for vaccine-based cancer immunotherapy.

\section{Bispecific T Cell Engagers}

Bispecific T cell engagers represent a novel therapeutic modality based on the fusion of two single-chain variable fragments $(\mathrm{scFv})$, one of which binds the target antigen while the other engages with T cells via CD3. Unlike classic monoclonal antibodies, BiTEs are designed to activate cytotoxic T cells against tumor cells. In 2011, a new CSPG4-targeting BiTE antibody was shown to induce antitumor effects in vitro via redirected lysis (100). Following incubation with healthy donor PBMCs, all of the 23 melanoma cell lines utilized in the study were successfully lysed in a dose- and effector:target ratio-dependent manner. Furthermore, the BiTE antibody showed promise in a melanoma patient setting in vitro by triggering cytotoxicity by melanoma patient-derived $\mathrm{T}$ cells against allogeneic or autologous melanoma cells. Another study reports important findings about the design of CSPG4-targeting BiTE therapeutics linked to the epitope distance to the target cell (101). Anti-CSPG4 BiTE antibodies proved much more potent when binding epitopes located closer to the cell membrane. This was proposed to be linked to the large size of the CSPG4 antigen and represents an important factor to consider for the design of antibody therapeutic agents with maximal potency.

\section{CAR T Cells}

Chimeric Antigen Receptor T cells represent another promising $\mathrm{T}$ cell-based therapeutic approach utilizing monoclonal antibodies whose efficacy against CSPG4 is being investigated. CAR T cells are genetically modified to express a chimeric receptor based on the targeting moiety of a $\mathrm{mAb}(\mathrm{scFv})$ recognizing the antigen of interest, to re-direct cytotoxic $\mathrm{T}$ cells toward tumor cells. The robust clinical success in the treatment of ALL has attracted a lot of attention on CAR T cell approaches, with one anti-CD19 based therapy expected to soon be granted FDA approval for the treatment of pediatric ALL (102). One of the first studies investigating the potential of anti-CSPG4 CAR T cells showed in vitro cytolytic potency against a variety of solid tumor cell lines including breast cancer, melanoma, mesothelioma, glioblastoma and osteosarcoma (103). Another study investigating anti-CSPG4 CAR T cells announced promising efficacy outcomes against melanoma, breast cancer and head and neck cancer in vitro and in vivo using cell line xenografts in mice (104).

Even though preclinical data on anti-CSPG4 CAR T cell therapy are encouraging, it remains to be established whether the clinical responses observed with CAR $\mathrm{T}$ cell treatments against liquid tumors can be reproduced in solid malignancies. A prominent limitation of the efficacious re-targeting of $\mathrm{T}$ cells against solid tumors is the tumor stroma, often inhibiting $\mathrm{T}$ cell trafficking and potency. Multiple approaches have been designed to address this issue, including the expression of chemokine receptors by the CAR T cells or in vivo tumor modification to encourage the secretion of T cell chemoattractants (105).

\section{Radioimmunotherapy}

Monoclonal antibodies recognizing CSPG4 could be conjugated to a radioactive isotope for radioimmunotherapy, designed to target radiation directly and more specifically to tumor cells, with the aim of reducing non-specific exposure of normal cells to the radioactive isotope. Targeted radioimmunotherapy may 
TABLE 1 | Antibody-based treatment approaches targeting CSPG4

\begin{tabular}{|c|c|c|c|c|c|c|c|c|c|}
\hline Treatment strategy & $\begin{array}{l}\text { Clone/ } \\
\text { construct }\end{array}$ & $\begin{array}{l}\text { Toxin } \\
\text { conjugate }\end{array}$ & $\begin{array}{l}\text { Treatment } \\
\text { combination }\end{array}$ & Antibody species & $\begin{array}{l}\text { In vitro model } \\
\text { and indication }\end{array}$ & $\begin{array}{l}\text { In vivo model and } \\
\text { indication }\end{array}$ & Proposed mechanism(s) of action & $\begin{array}{l}\text { Clinical } \\
\text { trial }\end{array}$ & $\begin{array}{l}\text { Key } \\
\text { reference }\end{array}$ \\
\hline Classic mAb & $225.28 S$ & MTX & $N / A$ & Full mouse antibody & $\begin{array}{l}\text { Melanoma cell } \\
\text { line }\end{array}$ & $\begin{array}{l}\text { Human melanoma } \\
\text { cell line xenograft; } \\
\text { nude mice }\end{array}$ & $\begin{array}{l}\text { Growth inhibition, delivery of cytotoxic } \\
\text { drugs to the tumor }\end{array}$ & N/A & (83) \\
\hline Classic mAb & $225.28 S$ & N/A & $\mathrm{N} / \mathrm{A}$ & Full mouse antibody & $\begin{array}{l}\text { Melanoma, } \\
\text { TNBC cell line }\end{array}$ & $\begin{array}{l}\text { Human melanoma } \\
\text { cell line xenograft; } \\
\text { SCID mice }\end{array}$ & $\begin{array}{l}\text { Disruption of the interaction between } \\
\text { the cancer cells and the ECM }\end{array}$ & $\mathrm{N} / \mathrm{A}$ & (84) \\
\hline Classic mAb & $225.28 S$ & $\mathrm{~N} / \mathrm{A}$ & $\mathrm{N} / \mathrm{A}$ & Full mouse antibody & TNBC cell line & $\begin{array}{l}\text { Human TNBC cell } \\
\text { line lung metastasis } \\
\text { model; SCID mice } \\
\text { Orthotopic human } \\
\text { TNBC cell line } \\
\text { xenograft; SCID mice }\end{array}$ & $\begin{array}{l}\text { Direct effects (growth, adhesion, and } \\
\text { migration inhibition) }\end{array}$ & N/A & (61) \\
\hline Classic mAb & 225.28S & N/A & $\begin{array}{l}\text { PLX4032 } \\
\text { (BRAF inhibitor) }\end{array}$ & Full mouse antibody & $\begin{array}{l}\text { Human } \\
\text { BRAFV600E mutant } \\
\text { melanoma cell } \\
\text { lines }\end{array}$ & $\mathrm{N} / \mathrm{A}$ & $\begin{array}{l}\text { Synergistic direct effects (growth, } \\
\text { migration, survival inhibition); delayed } \\
\text { BRAF inhibitor resistance }\end{array}$ & $\mathrm{N} / \mathrm{A}$ & (51) \\
\hline Classic mAb & $225.28 S$ & N/A & $\begin{array}{l}\text { Cytarbine } \\
\text { (chemotherapy) }\end{array}$ & Full mouse antibody & $\begin{array}{l}\text { 11q23 AML cell } \\
\text { line }\end{array}$ & $\begin{array}{l}\text { Human AML cell line } \\
\text { subcutaneous model; } \\
\text { SCID mice }\end{array}$ & $\begin{array}{l}\text { No direct effects (mAb alone); } \\
\text { synergistic antiproliferative effects with } \\
\text { Cytarbine; no in vivo effects on tumor } \\
\text { growth/animal survival }\end{array}$ & $N / A$ & (71) \\
\hline Classic mAb & $225.28 S$ & N/A & $N / A$ & $\begin{array}{l}\text { Chimeric antibody } \\
\text { (mouse Fab, human } \\
\text { Fc) }\end{array}$ & $\begin{array}{l}\text { Melanoma cell } \\
\text { lines }\end{array}$ & $\begin{array}{l}\text { Human melanoma } \\
\text { cell line xenograft; } \\
\text { human immune cell } \\
\text { engrafted NSG mice }\end{array}$ & $\begin{array}{l}\text { Immune mediated effects (ADCC/ } \\
\text { ADCP) }\end{array}$ & $\mathrm{N} / \mathrm{A}$ & (85) \\
\hline Classic mAb & TP41.2 & N/A & $N / A$ & Full mouse antibody & $\begin{array}{l}\text { Mesothelioma } \\
\text { cell line }\end{array}$ & $\begin{array}{l}\text { Human mesothelioma } \\
\text { cell line xenograft; } \\
\text { SCID mice }\end{array}$ & $\begin{array}{l}\text { Direct effects (cell growth, adhesion, } \\
\text { motility, migration, and invasiveness) }\end{array}$ & N/A & (86) \\
\hline Classic mAb & scFv-FcC21 & N/A & N/A & $\begin{array}{l}\text { Recombinant scFv } \\
\text { mAb with a human Fc } \\
\text { region }\end{array}$ & TNBC cell line & $\begin{array}{l}\text { Human melanoma } \\
\text { cell line xenograft; } \\
\text { SCID mice }\end{array}$ & $\begin{array}{l}\text { No immune mediated effects; direct } \\
\text { effects (cell growth and migration } \\
\text { inhibition) }\end{array}$ & N/A & $(43,87)$ \\
\hline Classic mAb & 9.2 .27 & PEG & $\begin{array}{l}\text { Adoptive } \\
\text { NK cell transfer }\end{array}$ & Full mouse antibody & $\mathrm{N} / \mathrm{A}$ & $\begin{array}{l}\text { Human GBM cell } \\
\text { line xenograft, } \\
\text { patient derived GBM } \\
\text { xenograft; athymic } \\
\text { rats }\end{array}$ & $\begin{array}{l}\text { Immune-mediated effects by } \\
\text { macrophages }\end{array}$ & N/A & (88) \\
\hline Classic mAb & Polyclonal mAbs & $\mathrm{N} / \mathrm{A}$ & $\begin{array}{l}\text { Vemurafenib } \\
\text { (BRAFv600E } \\
\text { inhibitor) }\end{array}$ & Full mouse antibody & $\begin{array}{l}\text { Human } \\
\text { BRAFV600E mutant } \\
\text { melanoma cell } \\
\text { lines }\end{array}$ & $\mathrm{N} / \mathrm{A}$ & $\begin{array}{l}\text { Synergistic direct effects (proliferation } \\
\text { and migration inhibition) }\end{array}$ & N/A & $(117)$ \\
\hline Anti-idiotypic mAb & MK2-23 & $N / A$ & $B C G$ & Full mouse antibody & $\mathrm{N} / \mathrm{A}$ & $\mathrm{N} / \mathrm{A}$ & $\begin{array}{l}\text { Induction of adaptive humoral immune } \\
\text { response }\end{array}$ & $\begin{array}{l}\text { Advanced } \\
\text { melanoma } \\
\text { patients; } \\
\text { Phase I/II }\end{array}$ & (93) \\
\hline
\end{tabular}


TABLE 1 | Continued

\begin{tabular}{|c|c|c|c|c|c|c|c|c|c|}
\hline Treatment strategy & $\begin{array}{l}\text { Clone/ } \\
\text { construct }\end{array}$ & $\begin{array}{l}\text { Toxin } \\
\text { conjugate }\end{array}$ & $\begin{array}{l}\text { Treatment } \\
\text { combination }\end{array}$ & Antibody species & $\begin{array}{l}\text { In vitro model } \\
\text { and indication }\end{array}$ & $\begin{array}{l}\text { In vivo model and } \\
\text { indication }\end{array}$ & Proposed mechanism(s) of action & $\begin{array}{l}\text { Clinical } \\
\text { trial }\end{array}$ & $\begin{array}{l}\text { Key } \\
\text { reference }\end{array}$ \\
\hline Anti-idiotypic mAb & MK2-23 & $\mathrm{IL}-2$ & $\mathrm{~N} / \mathrm{A}$ & Full mouse antibody & N/A & BALB/c mice & $\begin{array}{l}\text { Induction of adaptive humoral immune } \\
\text { response }\end{array}$ & $\mathrm{N} / \mathrm{A}$ & (94) \\
\hline Anti-idiotypic mAb & MF11-30 & $N / A$ & $\mathrm{~N} / \mathrm{A}$ & Full mouse antibody & N/A & N/A & $\begin{array}{l}\text { Induction of adaptive humoral immune } \\
\text { response }\end{array}$ & $\begin{array}{l}\text { Advanced } \\
\text { melanoma } \\
\text { patients; } \\
2 \times \\
\text { phase I }\end{array}$ & (96) \\
\hline BiTE & MCSP-BiTE & N/A & $N / A$ & $\begin{array}{l}\text { Recombinant BiTE } \\
\text { construct }\end{array}$ & $\begin{array}{l}\text { Human } \\
\text { melanoma cell } \\
\text { lines; melanoma } \\
\text { patient-derived } \\
\text { samples }\end{array}$ & N/A & $\begin{array}{l}\text { Cytotoxic T cell-mediated tumor cell } \\
\text { killing }\end{array}$ & N/A & $(100)$ \\
\hline BiTE & $\begin{array}{l}\text { MCSP120, } \\
\text { MCSP128, } \\
\text { MCSP113, } \\
\text { MCSP70 }\end{array}$ & N/A & $N / A$ & $\begin{array}{l}\text { Recombinant BiTE } \\
\text { construct based on } \\
\text { mouse hybridoma- } \\
\text { derived mAbs }\end{array}$ & $\begin{array}{l}\text { CHO cells } \\
\text { expressing } \\
\text { CSPG } 4 \text { domain } \\
\text { portions }\end{array}$ & N/A & $\begin{array}{l}\text { Cytotoxic T cell-mediated tumor cell } \\
\text { killing }\end{array}$ & N/A & (101) \\
\hline CAR & $\begin{array}{l}\text { CAR constructs } \\
\text { based on mAbs } \\
225.28 ; \text { TP41.2; } \\
149.53\end{array}$ & N/A & $\mathrm{N} / \mathrm{A}$ & $\begin{array}{l}\text { Recombinant CAR } \\
\text { construct, includes } \\
\text { mAb scFv region } \\
\text { based on mouse mAbs }\end{array}$ & $\begin{array}{l}\text { Human } \\
\text { melanoma, } \\
\text { breast cancer, } \\
\text { mesothelioma, } \\
\text { glioblastoma and } \\
\text { osteosarcoma } \\
\text { cell lines }\end{array}$ & N/A & $\begin{array}{l}\text { Cytotoxic CAR T cell-mediated tumor } \\
\text { cell killing }\end{array}$ & $N / A$ & (103) \\
\hline CAR & $\begin{array}{l}\text { CAR construct } \\
\text { based on mAb } \\
763.74\end{array}$ & N/A & $N / A$ & $\begin{array}{l}\text { Recombinant CAR } \\
\text { construct, includes } \\
\text { mAb scFv region } \\
\text { based on mouse mAbs }\end{array}$ & $\begin{array}{l}\text { Human, } \\
\text { melanoma, } \\
\text { HNSCC and } \\
\text { breast cancer } \\
\text { cell lines }\end{array}$ & $\begin{array}{l}\text { Human, melanoma, } \\
\text { HNSCC and breast } \\
\text { cancer cell line } \\
\text { xenografts; NSG mice }\end{array}$ & $\begin{array}{l}\text { Cytotoxic CAR T cell-mediated tumor } \\
\text { cell killing }\end{array}$ & N/A & $(104)$ \\
\hline CAR & $\begin{array}{l}\text { CAR construct } \\
\text { based on mAb } \\
225.28\end{array}$ & N/A & $\mathrm{N} / \mathrm{A}$ & $\begin{array}{l}\text { Recombinant CAR } \\
\text { construct, includes } \\
\text { mAb scFv region } \\
\text { based on mouse mAbs }\end{array}$ & $\begin{array}{l}\text { Human } \\
\text { melanoma cell } \\
\text { lines }\end{array}$ & N/A & $\begin{array}{l}\text { Cytotoxic CAR T cell-mediated tumor } \\
\text { cell killing }\end{array}$ & N/A & (119) \\
\hline Radioimmunotherapy & $\begin{array}{l}(213) \\
\text { Bi-cDTPA-9.2.27 } \\
\text { (based on mAb } \\
9.2 .27 \text { ) }\end{array}$ & (213)Bi-cDTPA & $\mathrm{N} / \mathrm{A}$ & Full mouse antibody & $\mathrm{N} / \mathrm{A}$ & N/A & $\begin{array}{l}\text { Radiotherapy induced targeted } \\
\text { cytotoxicity }\end{array}$ & $\begin{array}{l}\text { Advanced } \\
\text { melanoma } \\
\text { patients, } \\
\text { phase I }\end{array}$ & $(108)$ \\
\hline Radioimmunotherapy & $225.28 S$ & $212 \mathrm{~Pb}$ & $\mathrm{~N} / \mathrm{A}$ & Full mouse antibody & $\begin{array}{l}\text { Human TNBC } \\
\text { cell line }\end{array}$ & $\begin{array}{l}\text { Human TNBC cell line } \\
\text { xenograft; nude mice }\end{array}$ & $\begin{array}{l}\text { Radiotherapy induced targeted } \\
\text { cytotoxicity }\end{array}$ & N/A & (109) \\
\hline CFP & $\begin{array}{l}\alpha C S P G 4(s c F v)- \\
\text { MAP }\end{array}$ & MAP & N/A & $\begin{array}{l}\text { Recombinant } \\
\text { construct, scFv mAb } \\
\text { genetically fused to } \\
\text { MAP }\end{array}$ & $\begin{array}{l}\text { Human TNBC } \\
\text { cell line }\end{array}$ & $\begin{array}{l}\text { Human TNBC cell line } \\
\text { xenograft; BALB/c } \\
\text { mice }\end{array}$ & MAP induced targeted cytotoxicity & N/A & $(112)$ \\
\hline
\end{tabular}


be promising with regards to CSPG4, based on overexpression in advanced tumors, restricted distribution and lower levels of expression in normal tissues (106). So far, radioimmunotherapy has only been successfully applied for the treatment of patients with lymphoma, while most clinical trials in solid tumors have rarely reached phase III, often due to cost, or to stringent patient inclusion criteria (107). Nevertheless, the outcomes of a phase I clinical trial of (213)Bi-cDTPA-9.2.27 (based on the anti-CSPG4 $\mathrm{mAb}$ clone 9.2.27) in advanced melanoma indicated no toxicities, a $10 \%$ objective partial response rate (108). Furthermore, a more recent preclinical study evaluating $\mathrm{mAb} 225.28$ radiolabeled with $212 \mathrm{~Pb}$ showed efficacy against triple negative breast cancer cells expressing CSPG4, both in vivo and in vitro (109).

Based on these findings, radioactive isotope-conjugated anti-CSPG4 antibodies may yet hold promise for patients with CSPG4-expressing tumors.

\section{Cytolytic Fusion Proteins (CFPs)}

Cytolytic fusion proteins or immunotoxins, are classified as protein toxins, most commonly of plant or bacterial origin, genetically fused or conjugated to another protein (often an antibody or an antibody fragment), recognizing a cell surface target molecule and delivering the payload to the cancer cell (110).

The microtubule-associated protein tau, recently investigated as a toxin, primarily functions as a microtubule stabilizer and a regulator of cell division (111). Targeting CSPG4 using a scFv fused to MAP against TNBC cell lines in vitro and against human TNBC cell line xenografts in Balb/c mice showed similar antitumor efficacy to an anti-CSPG4 scFv conjugated to a chemotherapeutic agent, with no toxic effects in vivo (112).

Another interesting approach involves an anti-CSPG4 scFv conjugated to the TNF-related apoptosis-inducing ligand (TRAIL), a soluble protein ligand able to induce apoptosis through binding the cell surface-anchored TRAIL receptor. In a study investigating a TRAIL-fused anti-CSPG4 scFv (based on the $\mathrm{mAb}$ 9.2.27), the novel therapeutic candidate showed potent in vitro activity against melanoma cell lines, but no off-target effects on normal melanocytes $(113,114)$. Moreover, it restricted the growth of a human melanoma xenograft in athymic mice.

Both CFP examples suggest that this may represent a promising targeted delivery alternative to chemotherapy, especially for antigens such as CSPG4 with high expression in tumors and restricted expression in normal tissues.

\section{COMBINATION THERAPIES AND OTHER APPLICATIONS}

BRAF inhibitors, now approved for the treatment of patients with melanomas bearing mutant forms of BRAF, are often only effective for a short time before cancer recurs, due to intrinsic and acquired pathway resistance (115). Therefore, alternative treatments and treatment combinations that may overcome resistance mechanisms are desirable (116). The anti-CSPG4 mAb 225.28 combined with a BRAF inhibitor exhibited synergistic antitumor effects and enhanced efficacy against $\mathrm{BRAF}^{\mathrm{V} 600 \mathrm{E}}$ mutant melanoma cells in vitro compared to either agent alone (51). Furthermore, the $\mathrm{mAb}$ was shown to delay the development of resistance by 
melanoma cells. More recently, Pucciarelli et al. showed that combining polyclonal anti-CSPG4 antibodies, induced by mimotope vaccination, with the BRAF inhibitor vemurafenib synergistically reduced the proliferation and migration of melanoma cells in vitro (117). These preliminary findings suggest that combining anti-CSPG4 antibodies with pathway inhibitors may enhance the restricted success of BRAF inhibitors in melanoma.

Cancer theranostic agents, combining both diagnostic and therapeutic treatment in one targeted molecule are an emerging modality. As with other antibody therapeutic applications, CSPG4 has been recognized as a promising candidate for theranostic applications, based on high expression by tumor cells and low expression by healthy cells. In an in vitro photo-immunotheranostic study, single-chain variable fragment ( $\mathrm{scFv}$ ) antibodies recognizing TNBC targets, including CSPG4, as well as epidermal growth factor receptor (EGFR) and epithelial cell adhesion molecule (EpCAM), were conjugated to a potent photosensitizing agent and were used to target TNBC cell lines and tumor biopsy samples (118). The conjugated scFvs demonstrated high quality imaging capacity, and triggered apoptosis of cancer cells via induction of reactive oxygen species. Moreover, combinatorial administration of all three conjugated scFv antibodies together, increased cytotoxic activity against breast cancer cells in vitro by up to $40 \%$ compared with treatment by each individual agent alone. Further findings are awaited to confirm and provide further efficacy insights on these encouraging outcomes in future in vivo studies.

\section{CONCLUSION AND FUTURE DIRECTIONS}

Despite advances in immunotherapy such as the emergence of checkpoint inhibitors for melanoma, mAb, or CAR T cell strategies that specifically target melanoma cells are still lacking. Localized overexpression in several aggressive tumor types and in tumor vasculature, combined with low and restricted distribution in normal tissues, as well as evidence for important functions to support cancer growth, angiogenesis and dissemination, represent important attributes that identify CSPG4 as a promising target for therapeutic approaches, including monoclonal antibodies (Table 1). Importantly, in order to develop more successful therapeutics, a better understanding of the functions of CSPG4 in cancer and its interaction with the immune system and the tumor immune stroma are urgently needed.

While many treatment strategies centered on CSPG4 appear to have had success both in vitro and in vivo in rodent models, the next steps require in-depth studies with humanized or human antibodies, in disease-relevant and in clinically congruent models of cancer, including animal models engrafted with components of human immunity. These will permit mechanistic and efficacy evaluations in systems better able to recapitulate the patient setting.

An exciting prospect for targeting CSPG4 is the observed synergy between anti-CSPG4 monoclonal antibodies and BRAF inhibitors. In melanoma, a proportion of patients' tumors have constitutively activated BRAF. Small molecule inhibitors recognizing mutant forms of BRAF have proved very effective. However, clinical responses are often short-lived due to the emergence of resistance. Combinatorial studies of monoclonal anti-CSPG4 antibodies with BRAF inhibitors have demonstrated enhanced effects and delayed the occurrence of resistance. Further understanding of the mechanisms that underpin the efficacy of these and other combinatory strategies may offer important clues that stand to improve current treatments.

Additionally, targeting CSPG4 may lead to targeted therapy for triple-negative breast cancer patients who do not benefit from therapies apart from standard chemotherapy. Therefore, further research and translation into clinical trials could be especially beneficial for the TNBC patient group.

As with all therapeutic approaches, the benefits of treatment must be balanced with the likelihood and severity of adverse effects. CSPG4 is expressed at low levels in some normal tissues; therefore, it is important to evaluate and mitigate any ontarget, off-tumor toxic effects of CSPG4-specific targeted therapy. Encouragingly, a phase I clinical trial investigating anti-CSPG4 radioimmunotherapy with a $\mathrm{mAb}(9.2 .27)$ conjugated to an $\alpha$-particle-emitting radioisotope which was administered systemically in patients with melanoma reported no adverse events while some clinical benefits were observed (108). Furthermore, CSPG4-based immunotherapy strategies would benefit from the development of more effective methods of treatment delivery, such as hypobaric pressure skin delivery, which would limit potential off-target effects and reduce the cost of the therapy (120).

The emergence of novel antibody-based approaches offers fresh optimism that aggressive cancers, such as TNBC, glioma and head and neck carcinomas, which do not benefit from currently available therapies, but for which CSPG4 expression and its tumor-promoting functions have been reported, may become responsive to treatments based on this target. Therefore, renewed focus on CSPG4 may in future translate into significant benefits for patients with cancer.

\section{AUTHOR CONTRIBUTIONS}

$\mathrm{KI}, \mathrm{SK}$, and AT conceived and designed the study. KI, AC, SM, GC, SC, MG, MN searched and studied the literature. KI, MG, SK and AT wrote the manuscript. AC, SM, GC, MN, JS, ST, KE discussed and interpreted the literature findings and helped to edit the manuscript. SK supervised the study.

\section{FUNDING}

This work is supported by Breast Cancer Now (147) working in partnership with Walk the Walk; Cancer Research UK (C30122/ A11527; C30122/A15774); The Academy of Medical Sciences; the Medical Research Council (MR/L023091/1); Cancer Research UK King's Health Partners Centre at King's College London; CRUK/ NIHR in England/DoH for Scotland, Wales and Northern Ireland Experimental Cancer Medicine Centre (C10355/A15587); The British Skin Foundation (S633); The Dermatrust; Guy's and St Thomas's Charity Melanoma Special Fund; BBSRC IBCarb Network (Proof-of-Concept award IBCarb-PoC-0616-040). The research was supported by the National Institute for Health Research (NIHR) Biomedical Research Centre (BRC) based at Guy's and St Thomas' NHS Foundation Trust and King's College London (IS-BRC-1215-20006). The views expressed are those of the author(s) and not necessarily those of the NHS, the NIHR or the Department of Health. 


\section{REFERENCES}

1. Wilson BS, Imai K, Natali PG, Ferrone S. Distribution and molecular characterization of a cell-surface and a cytoplasmic antigen detectable in human melanoma cells with monoclonal antibodies. Int J Cancer (1981) 28:293-300. doi:10.1002/ijc.2910280307

2. Kozanoglu I, Boga C, Ozdogu H, Sozer O, Maytalman E, Yazici AC, et al. Human bone marrow mesenchymal cells express NG2: possible increase in discriminativeability offlow cytometry during mesenchymal stromalcellidentification. Cytotherapy (2009) 11:527-33. doi:10.1080/14653240902923153

3. Ziai MR, Imberti L, Nicotra MR, Badaracco G, Segatto O, Natali PG, et al. Analysis with monoclonal antibodies of the molecular and cellular heterogeneity of human high molecular weight melanoma associated antigen. Cancer Res (1987) 47:2474-80.

4. Giacomini P, Veglia F, Cordiali Fei P, Rehle T, Natali PG, Ferrone S. Level of a membrane-bound high-molecular-weight melanoma-associated antigen and a cytoplasmic melanoma-associated antigen in surgically removed tissues and in sera from patients with melanoma. Cancer Res (1984) 44:1281-7.

5. Fukushi J, Inatani M, Yamaguchi Y, Stallcup WB. Expression of NG2 proteoglycan during endochondral and intramembranous ossification. Dev Dyn (2003) 228:143-8. doi:10.1002/dvdy.10359

6. Natali P, Bigotti A, Cavalieri R, Wakabayaski S, Taniguchi M, Ferrone S. Distribution of a cross-species melanoma-associated antigen in normal and neoplastic human tissues. J Invest Dermatol (1985) 85:340-6. doi:10.1111/1523-1747.ep12276944

7. Midwood KS, Salter DM. Expression of NG2/human melanoma proteoglycan in human adult articular chondrocytes. Osteoarthritis Cartilage (1998) 6:297-305. doi:10.1053/joca.1998.0128

8. Bu J, Akhtar N, Nishiyama A. Transient expression of the NG2 proteoglycan by a subpopulation of activated macrophages in an excitotoxic hippocampal lesion. Glia (2001) 34:296-310. doi:10.1002/glia.1063

9. Jones LL, Yamaguchi Y, Stallcup WB, Tuszynski MH. NG2 is a major chondroitin sulfate proteoglycan produced after spinal cord injury and is expressed by macrophages and oligodendrocyte progenitors. JNeurosci (2002) 22(7):2792-803.

10. Stallcup WB, You WK, Kucharova K, Cejudo-Martin P, Yotsumoto F. NG2 proteoglycan-dependent contributions of pericytes and macrophages to brain tumor vascularization and progression. Microcirculation (2016) 23:122-33. doi:10.1111/micc.12251

11. Tigges U, Hyer EG, Scharf J, Stallcup WB. FGF2-dependent neovascularization of subcutaneous Matrigel plugs is initiated by bone marrow-derived pericytes and macrophages. Development (2008) 135:523-32. doi:10.1242/ dev.002071

12. Beard RE, Abate-Daga D, Rosati SF, Zheng Z, Wunderlich JR, Rosenberg SA, et al. Gene expression profiling using nanostring digital RNA counting to identify potential target antigens for melanoma immunotherapy. Clin Cancer Res (2013) 19:4941-50. doi:10.1158/1078-0432.CCR-13-1253

13. Van Sinderen M, Cuman C, Winship A, Menkhorst E, Dimitriadis E. The chrondroitin sulfate proteoglycan (CSPG4) regulates human trophoblast function. Placenta (2013) 34:907-12. doi:10.1016/j.placenta.2013.07.065

14. Fukushi J, Makagiansar IT, Stallcup WB. NG2 proteoglycan promotes endothelial cell motility and angiogenesis via engagement of galectin-3 and alpha3beta1 integrin. Mol Biol Cell (2004) 15:3580-90. doi:10.1091/mbc. E04-03-0236

15. Sakry D, Neitz A, Singh J, Frischknecht R, Marongiu D, Biname F, et al. Oligodendrocyte precursor cells modulate the neuronal network by activity-dependent ectodomain cleavage of glial NG2. PLoS Biol (2014) 12:e1001993. doi:10.1371/journal.pbio.1001993

16. Legg J, Jensen UB, Broad S, Leigh I, Watt FM. Role of melanoma chondroitin sulphate proteoglycan in patterning stem cells in human interfollicular epidermis. Development (2003) 130:6049-63. doi:10.1242/dev.00837

17. Ampofo E, Schmitt BM, Menger MD, Laschke MW. The regulatory mechanisms of NG2/CSPG4 expression. Cell Mol Biol Lett (2017) 22:4. doi:10.1186/ s11658-017-0035-3

18. Pluschke G, Vanek M, Evans A, Dittmar T, Schmid P, Itin P, et al. Molecular cloning of a human melanoma-associated chondroitin sulfate proteoglycan. Proc Natl Acad Sci U S A (1996) 93:9710-5. doi:10.1073/ pnas.93.18.9710
19. Nishiyama A, Dahlin KJ, Prince JT, Johnstone SR, Stallcup WB. The primary structure of NG2, a novel membrane-spanning proteoglycan. J Cell Biol (1991) 114:359-71. doi:10.1083/jcb.114.2.359

20. Timpl R, Tisi D, Talts JF, Andac Z, Sasaki T, Hohenester E. Structure and function of laminin LG modules. Matrix Biol (2000) 19:309-17. doi:10.1016/ S0945-053X(00)00072-X

21. Iida J, Wilhelmson KL, Ng J, Lee P, Morrison C, Tam E, et al. Cell surface chondroitin sulfate glycosaminoglycan in melanoma: role in the activation of pro-MMP-2 (pro-gelatinase A). Biochem J (2007) 403:553-63. doi:10.1042/ BJ20061176

22. Iida J, Meijne AM, Oegema TR Jr, Yednock TA, Kovach NL, Furcht LT, et al. A role of chondroitin sulfate glycosaminoglycan binding site in alpha4beta1 integrin-mediated melanoma cell adhesion. J Biol Chem (1998) 273:5955-62. doi:10.1074/jbc.273.10.5955

23. Tillet E, Ruggiero F, Nishiyama A, Stallcup WB. The membrane-spanning proteoglycan NG2 binds to collagens V and VI through the central nonglobular domain of its core protein. J Biol Chem (1997) 272:10769-76. doi:10.1074/jbc.272.16.10769

24. Tillet E, Gential B, Garrone R, Stallcup WB. NG2 proteoglycan mediates betal integrin-independent cell adhesion and spreading on collagen VI. J Cell Biochem (2002) 86:726-36. doi:10.1002/jcb.10268

25. Nishiyama A, Lin XH, Giese N, Heldin CH, Stallcup WB. Interaction between NG2 proteoglycan and PDGF alpha-receptor on O2A progenitor cells is required for optimal response to PDGF. J Neurosci Res (1996) 43:315-30. doi:10.1002/(SICI)1097-4547(19960201)43:3<315::AID-JNR6>3.0.CO;2-M

26. Grako KA, Ochiya T, Barritt D, Nishiyama A, Stallcup WB. PDGF (alpha)-receptor is unresponsive to PDGF-AA in aortic smooth muscle cells from the NG2 knockout mouse. J Cell Sci (1999) 112(Pt 6):905-15.

27. Iida J, Pei D, Kang T, Simpson MA, Herlyn M, Furcht LT, et al. Melanoma chondroitin sulfate proteoglycan regulates matrix metalloproteinase-dependent human melanoma invasion into type I collagen. J Biol Chem (2001) 276:18786-94. doi:10.1074/jbc.M010053200

28. Wen Y, Makagiansar IT, Fukushi J, Liu FT, Fukuda MN, Stallcup WB. Molecular basis of interaction between NG2 proteoglycan and galectin-3. J Cell Biochem (2006) 98:115-27. doi:10.1002/jcb.20768

29. Vergilis IJ, Szarek M, Ferrone S, Reynolds SR. Presence and prognostic significance of melanoma-associated antigens CYT-MAA and HMW-MAA in serum of patients with melanoma. J Invest Dermatol (2005) 125:526-31. doi:10.1111/j.0022-202X.2005.23798.x

30. Feutlinske F, Browarski M, Ku MC, Trnka P, Waiczies S, Niendorf T, et al. Stonin1 mediates endocytosis of the proteoglycan NG2 and regulates focal adhesion dynamics and cell motility. Nat Commun (2015) 6:8535. doi:10.1038/ncomms9535

31. Barritt DS, Pearn MT, Zisch AH, Lee SS, Javier RT, Pasquale EB, et al. The multi-PDZ domain protein MUPP1 is a cytoplasmic ligand for the membrane-spanning proteoglycan NG2. J Cell Biochem (2000) 79:213-24. doi:10.1002/1097-4644(20001101)79:2<213::AID-JCB50>3.0.CO;2-G

32. Campoli M, Ferrone S, Wang X. Functional and clinical relevance of chondroitin sulfate proteoglycan 4. Adv Cancer Res (2010) 109:73-121. doi:10.1016/B978-0-12-380890-5.00003-X

33. Makagiansar IT, Williams S, Mustelin T, Stallcup WB. Differential phosphorylation of NG2 proteoglycan by ERK and PKCalpha helps balance cell proliferation and migration. J Cell Biol (2007) 178:155-65. doi:10.1083/ jcb.200612084

34. Makagiansar IT, Williams S, Dahlin-Huppe K, Fukushi J, Mustelin T, Stallcup WB. Phosphorylation of NG2 proteoglycan by protein kinase C-alpha regulates polarized membrane distribution and cell motility. J Biol Chem (2004) 279:55262-70. doi:10.1074/jbc.M411045200

35. Yang J, Price MA, Neudauer CL, Wilson C, Ferrone S, Xia H, et al. Melanoma chondroitin sulfate proteoglycan enhances FAK and ERK activation by distinct mechanisms. J Cell Biol (2004) 165:881-91. doi:10.1083/jcb.200403174

36. Price MA, Colvin Wanshura LE, Yang J, Carlson J, Xiang B, Li G, et al. CSPG4, a potential therapeutic target, facilitates malignant progression of melanoma. Pigment Cell Melanoma Res (2011) 24:1148-57. doi:10.1111/j.1755-148X.2011.00929.x

37. Kucharova K, Stallcup WB. The NG2 proteoglycan promotes oligodendrocyte progenitor proliferation and developmental myelination. Neuroscience (2010) 166:185-94. doi:10.1016/j.neuroscience.2009.12.014 
38. Nicolosi PA, Dallatomasina A, Perris R. Theranostic impact of NG2/ CSPG4 proteoglycan in cancer. Theranostics (2015) 5:530-44. doi:10.7150/ thno. 10824

39. Russell KC, Tucker HA, Bunnell BA, Andreeff M, Schober W, Gaynor AS, et al. Cell-surface expression of neuron-glial antigen 2 (NG2) and melanoma cell adhesion molecule (CD146) in heterogeneous cultures of marrow-derived mesenchymal stem cells. Tissue Eng Part A (2013) 19:2253-66. doi:10.1089/ ten.tea.2012.0649

40. Gazziola C, Cordani N, Wasserman B, Carta S, Colombatti A, Perris R. Malignant fibrous histiocytoma: a proposed cellular origin and identification of its characterizing gene transcripts. Int J Oncol (2003) 23:343-51. doi:10.3892/ijo.23.2.343

41. Hughes EG, Kang SH, Fukaya M, Bergles DE. Oligodendrocyte progenitors balance growth with self-repulsion to achieve homeostasis in the adult brain. Nat Neurosci (2013) 16:668-76. doi:10.1038/nn.3390

42. Benassi MS, Pazzaglia L, Chiechi A, Alberghini M, Conti A, Cattaruzza S, et al. NG2 expression predicts the metastasis formation in soft-tissue sarcoma patients. J Orthop Res (2009) 27:135-40. doi:10.1002/jor.20694

43. Wang J, Svendsen A, Kmiecik J, Immervoll H, Skaftnesmo KO, Planaguma J, et al. Targeting the NG2/CSPG4 proteoglycan retards tumour growth and angiogenesis in preclinical models of GBM and melanoma. PLoS One (2011) 6:e23062. doi:10.1371/journal.pone.0023062

44. Volz NB, Stintzing S, Zhang W, Yang D, Ning Y, Wakatsuki T, et al. Genes involved in pericyte-driven tumor maturation predict treatment benefit of first-line FOLFIRI plus bevacizumab in patients with metastatic colorectal cancer. Pharmacogenomics J (2015) 15:69-76. doi:10.1038/tpj.2014.40

45. Onder TT, Gupta PB, Mani SA, Yang J, Lander ES, Weinberg RA. Loss of E-cadherin promotes metastasis via multiple downstream transcriptional pathways. Cancer Res (2008) 68:3645-54. doi:10.1158/0008-5472. CAN-07-2938

46. Yajima I, Kumasaka MY, Thang ND, Goto Y, Takeda K, Iida M, et al. Molecular network associated with MITF in skin melanoma development and progression. J Skin Cancer (2011) 2011:730170. doi:10.1155/2011/730170

47. Molina DM, Grewal S, Bardwell L. Characterization of an ERK-binding domain in microphthalmia-associated transcription factor and differential inhibition of ERK2-mediated substrate phosphorylation. J Biol Chem (2005) 280:42051-60. doi:10.1074/jbc.M510590200

48. Cheli Y, Giuliano S, Fenouille N, Allegra M, Hofman V, Hofman P, et al. Hypoxia and MITF control metastatic behaviour in mouse and human melanoma cells. Oncogene (2012) 31:2461-70. doi:10.1038/onc.2011.425

49. Mansky KC, Marfatia K, Purdom GH, Luchin A, Hume DA, Ostrowski MC. The microphthalmia transcription factor (MITF) contains two N-terminal domains required for transactivation of osteoclast target promoters and rescue of mi mutant osteoclasts. J Leukoc Biol (2002) 71:295-303. Available at: http://www.jleukbio.org/content/71/2/295

50. Yang J, Price MA, Li GY, Bar-Eli M, Salgia R, Jagedeeswaran R, et al. Melanoma proteoglycan modifies gene expression to stimulate tumor cell motility, growth, and epithelial-to-mesenchymal transition. Cancer Res (2009) 69:7538-47. doi:10.1158/0008-5472.CAN-08-4626

51. Yu L, Favoino E, Wang Y, Ma Y, Deng X, Wang X. The CSPG4-specific monoclonal antibody enhances and prolongs the effects of the BRAF inhibitor in melanoma cells. Immunol Res (2011) 50:294-302. doi:10.1007/s12026-0118232-z

52. Dimou L, Gallo V. NG2-glia and their functions in the central nervous system. Glia (2015) 63:1429-51. doi:10.1002/glia.22859

53. Louis DN, Holland EC, Cairncross JG. Glioma classification: a molecular reappraisal. Am J Pathol (2001) 159:779-86. doi:10.1016/S0002-9440(10)61750-6

54. Wade A, Robinson AE, Engler JR, Petritsch C, James CD, Phillips JJ. Proteoglycans and their roles in brain cancer. FEBS J (2013) 280:2399-417. doi:10.1111/febs.12109

55. Yadavilli S, Hwang EI, Packer RJ, Nazarian J. The role of NG2 proteoglycan in glioma. Transl Oncol (2016) 9:57-63. doi:10.1016/j.tranon.2015.12.005

56. Burg MA, Nishiyama A, Stallcup WB. A central segment of the NG2 proteoglycan is critical for the ability of glioma cells to bind and migrate toward type VI collagen. Exp Cell Res (1997) 235:254-64. doi:10.1006/excr.1997.3674

57. Brekke C, Lundervold A, Enger PO, Brekken C, Stalsett E, Pedersen TB, et al. NG2 expression regulates vascular morphology and function in human brain tumours. Neuroimage (2006) 29:965-76. doi:10.1016/j.neuroimage.2005.08.026
58. Yadavilli S, Scafidi J, Becher OJ, Saratsis AM, Hiner RL, Kambhampati M, et al. The emerging role of NG2 in pediatric diffuse intrinsic pontine glioma. Oncotarget (2015) 6:12141-55. doi:10.18632/oncotarget.3716

59. Higgins SC, Bolteus AJ, Donovan LK, Hasegawa H, Doey L, Al Sarraj S, et al. Expression of the chondroitin sulphate proteoglycan, NG2, in paediatric brain tumors. Anticancer Res (2014) 34:6919-24. Available at: http://ar.iiarjournals. org/content/34/12/6919.full

60. Parker K, Pilkington GJ. Morphological, immunocytochemical and flow cytometric in vitro characterisation of a surface-adherent medulloblastoma. Anticancer Res (2005) 25:3855-63. Available at: http://ar.iiarjournals.org/ content $/ 25 / 6 \mathrm{~B} / 3855$.long

61. Wang X, Osada T, Wang Y, Yu L, Sakakura K, Katayama A, et al. CSPG4 protein as a new target for the antibody-based immunotherapy of triple-negative breast cancer. J Natl Cancer Inst (2010) 102:1496-512. doi:10.1093/jnci/djq343

62. Hsu NC, Nien PY, Yokoyama KK, Chu PY, Hou MF. High chondroitin sulfate proteoglycan 4 expression correlates with poor outcome in patients with breast cancer. Biochem Biophys Res Commun (2013) 441:514-8. doi:10.1016/j. bbrc.2013.10.093

63. Cooney CA, Jousheghany F, Yao-Borengasser A, Phanavanh B, Gomes T, Kieber-Emmons AM, et al. Chondroitin sulfates play a major role in breast cancer metastasis: a role for CSPG4 and CHST11 gene expression in forming surface P-selectin ligands in aggressive breast cancer cells. Breast Cancer Res (2011) 13:R58. doi:10.1186/bcr2895

64. Laubli H, Borsig L. Selectins promote tumor metastasis. Semin Cancer Biol (2010) 20:169-77. doi:10.1016/j.semcancer.2010.04.005

65. Warta R, Herold-Mende C, Chaisaingmongkol J, Popanda O, Mock A, Mogler C, et al. Reduced promoter methylation and increased expression of CSPG4 negatively influences survival of HNSCC patients. Int J Cancer (2014) 135:2727-34. doi:10.1002/ijc.28906

66. Sato S, Tang YJ, Wei Q, Hirata M, Weng A, Han I, et al. Mesenchymal tumors can derive from $\mathrm{Ng} 2 / \mathrm{Cspg} 4$-expressing pericytes with beta-catenin modulating the neoplastic phenotype. Cell Rep (2016) 16:917-27. doi:10.1016/j. celrep.2016.06.058

67. Cattaruzza S, Nicolosi PA, Braghetta P, Pazzaglia L, Benassi MS, Picci P, et al. NG2/CSPG4-collagen type VI interplays putatively involved in the microenvironmental control of tumour engraftment and local expansion. J Mol Cell Biol (2013) 5:176-93. doi:10.1093/jmcb/mjt010

68. Wuchter C, Harbott J, Schoch C, Schnittger S, Borkhardt A, Karawajew L, et al. Detection of acute leukemia cells with mixed lineage leukemia (MLL) gene rearrangements by flow cytometry using monoclonal antibody 7.1. Leukemia (2000) 14:1232-8. doi:10.1038/sj.leu.2401840

69. Schwartz S, Rieder H, Schlager B, Burmeister T, Fischer L, Thiel E. Expression of the human homologue of rat NG2 in adult acute lymphoblastic leukemia: close association with MLL rearrangement and a CD10(-)/CD24(-)/ CD65s(+)/CD15(+) B-cell phenotype. Leukemia (2003) 17:1589-95. doi:10.1038/sj.leu.2402989

70. Hilden JM, Smith FO, Frestedt JL, McGlennen R, Howells WB, Sorensen PH, et al. MLL gene rearrangement, cytogenetic 11q23 abnormalities, and expression of the NG2 molecule in infant acute myeloid leukemia. Blood (1997) 89:3801-5.

71. Drake AS, Brady MT, Wang XH, Sait SJ, Earp JC, Ghoshal Gupta S, et al. Targeting 11q23 positive acute leukemia cells with high molecular weight-melanoma associated antigen-specific monoclonal antibodies. Cancer Immunol Immunother (2009) 58:415-27. doi:10.1007/s00262-008-0567-5

72. Rachmilewitz J, Tykocinski ML. Differential effects of chondroitin sulfates A and B on monocyte and B-cell activation: evidence for B-cell activation via a CD44-dependent pathway. Blood (1998) 92:223-9.

73. Aoyama E, Yoshihara R, Tai A, Yamamoto I, Gohda E. PKC- and PI3Kdependent but ERK-independent proliferation of murine splenic B cells stimulated by chondroitin sulfate B. Immunol Lett (2005) 99:80-4. doi:10.1016/j. imlet.2005.01.005

74. Yang R, Yan Z, Chen F, Hansson GK, Kiessling R. Hyaluronic acid and chondroitin sulphate A rapidly promote differentiation of immature DC with upregulation of costimulatory and antigen-presenting molecules, and enhancement of NF-kappaB and protein kinase activity. Scand J Immunol (2002) 55:2-13. doi:10.1046/j.0300-9475.2001.01033.x

75. Sakai S, Akiyama H, Harikai N, Toyoda H, Toida T, Maitani T, et al. Effect of chondroitin sulfate on murine splenocytes sensitized with ovalbumin. Immunol Lett (2002) 84:211-6. doi:10.1016/S0165-2478(02)00181-5 
76. Wang JY, Roehrl MH. Glycosaminoglycans are a potential cause of rheumatoid arthritis. Proc Natl Acad Sci U S A (2002) 99:14362-7. doi:10.1073/ pnas. 222536599

77. Rolls A, Cahalon L, Bakalash S, Avidan H, Lider O, Schwartz M. A sulfated disaccharide derived from chondroitin sulfate proteoglycan protects against inflammation-associated neurodegeneration. FASEB J (2006) 20:547-9. doi:10.1096/fj.05-4540fje

78. MacDermott RP, Schmidt RE, Caulfield JP, Hein A, Bartley GT, Ritz J, et al. Proteoglycans in cell-mediated cytotoxicity. Identification, localization, and exocytosis of a chondroitin sulfate proteoglycan from human cloned natural killer cells during target cell lysis. J Exp Med (1985) 162:1771-87. doi:10.1084/jem.162.6.1771

79. Phelps RA, Broadbent TJ, Stafforini DM, Jones DA. New perspectives on APC control of cell fate and proliferation in colorectal cancer. Cell Cycle (2009) 8:2549-56. doi:10.4161/cc.8.16.9278

80. Uhlin-Hansen L, Wik T, Kjellen L, Berg E, Forsdahl F, Kolset SO. Proteoglycan metabolism in normal and inflammatory human macrophages. Blood (1993) 82:2880-9.

81. Erfurt C, Sun Z, Haendle I, Schuler-Thurner B, Heirman C, Thielemans K, et al. Tumor-reactive CD4+ $\mathrm{T}$ cell responses to the melanoma-associated chondroitin sulphate proteoglycan in melanoma patients and healthy individuals in the absence of autoimmunity. J Immunol (2007) 178:7703-9. doi:10.4049/jimmunol.178.12.7703

82. Gao Q, Lu J, Huo Y, Baby N, Ling EA, Dheen ST. NG2, a member of chondroitin sulfate proteoglycans family mediates the inflammatory response of activated microglia. Neuroscience (2010) 165:386-94. doi:10.1016/j. neuroscience.2009.10.022

83. Ghose T, Ferrone S, Blair AH, Kralovec Y, Temponi M, Singh M, et al. Regression of human melanoma xenografts in nude mice injected with methotrexate linked to monoclonal antibody 225.28 to human high molecular weight-melanoma associated antigen. Cancer Immunol Immunother (1991) 34:90-6. doi:10.1007/BF01741341

84. Hafner C, Breiteneder H, Ferrone S, Thallinger C, Wagner S, Schmidt WM, et al. Suppression of human melanoma tumor growth in SCID mice by a human high molecular weight-melanoma associated antigen (HMW-MAA) specific monoclonal antibody. Int J Cancer (2005) 114:426-32. doi:10.1002/ ijc. 20769

85. Karagiannis P, Gilbert AE, Josephs DH, Ali N, Dodev T, Saul L, et al. IgG4 subclass antibodies impair antitumor immunity in melanoma. J Clin Invest (2013) 123:1457-74. doi:10.1172/JCI65579

86. Rivera Z, Ferrone S, Wang X, Jube S, Yang H, Pass HI, et al. CSPG4 as a target of antibody-based immunotherapy for malignant mesothelioma. Clin Cancer Res (2012) 18:5352-63. doi:10.1158/1078-0432.CCR-12-0628

87. Wang X, Katayama A, Wang Y, Yu L, Favoino E, Sakakura K, et al. Functional characterization of an scFv-Fc antibody that immunotherapeutically targets the common cancer cell surface proteoglycan CSPG4. Cancer Res (2011) 71:7410-22. doi:10.1158/0008-5472.CAN-10-1134

88. Poli A, Wang J, Domingues O, Planaguma J, Yan T, Rygh CB, et al. Targeting glioblastoma with NK cells and mAb against NG2/CSPG4 prolongs animal survival. Oncotarget (2013) 4:1527-46. doi:10.18632/oncotarget.1291

89. Campoli MR, Chang CC, Kageshita T, Wang X, McCarthy JB, Ferrone S. Human high molecular weight-melanoma-associated antigen (HMWMAA): a melanoma cell surface chondroitin sulfate proteoglycan (MSCP) with biological and clinical significance. Crit Rev Immunol (2004) 24:267-96. doi:10.1615/CritRevImmunol.v24.i4.40

90. Harper JR, Bumol TF, Reisfeld RA. Serological and biochemical analyses of monoclonal antibodies to human melanoma-associated antigens. Hybridoma (1982) 1:423-32. doi:10.1089/hyb.1.1982.1.423

91. Pan Y, Yuhasz SC, Amzel LM. Anti-idiotypic antibodies: biological function and structural studies. FASEB J (1995) 9:43-9.

92. Rolih V, Barutello G, Iussich S, De Maria R, Quaglino E, Buracco P, et al. CSPG4: a prototype oncoantigen for translational immunotherapy studies. J Transl Med (2017) 15:151. doi:10.1186/s12967-017-1250-4

93. Mittelman A, Chen ZJ, Yang H, Wong GY, Ferrone S. Human high molecular weight melanoma-associated antigen (HMW-MAA) mimicry by mouse anti-idiotypic monoclonal antibody MK2-23: induction of humoral antiHMW-MAA immunity and prolongation of survival in patients with stage IV melanoma. Proc Natl Acad Sci U S A (1992) 89:466-70. doi:10.1073/ pnas.89.2.466
94. Wang X, Ko EC, Peng L, Gillies SD, Ferrone S. Human high molecular weight melanoma-associated antigen mimicry by mouse anti-idiotypic monoclonal antibody MK2-23: enhancement of immunogenicity of anti-idiotypic monoclonal antibody MK2-23 by fusion with interleukin 2. Cancer Res (2005) 65:6976-83. doi:10.1158/0008-5472.CAN-04-2328

95. Barucca A, Capitani M, Cesca M, Tomassoni D, Kazmi U, Concetti F, et al. Recombinant DNA technology for melanoma immunotherapy: anti-Id DNA vaccines targeting high molecular weight melanoma-associated antigen. $\mathrm{Mol}$ Biotechnol (2014) 56:1032-9. doi:10.1007/s12033-014-9782-9

96. Mittelman A, Chen ZJ, Kageshita T, Yang H, Yamada M, Baskind P, et al. Active specific immunotherapy in patients with melanoma. A clinical trial with mouse anti idiotypic monoclonal antibodies elicited with syngeneic anti-high-molecular-weight-melanoma-associated antigen monoclonal antibodies. J Clin Invest (1990) 86:2136-44. doi:10.1172/JCI114952

97. Riemer AB, Hantusch B, Sponer B, Kraml G, Hafner C, Zielinski CC, et al. High-molecular-weight melanoma-associated antigen mimotope immunizations induce antibodies recognizing melanoma cells. Cancer Immunol Immunother (2005) 54:677-84. doi:10.1007/s00262-004-0632-7

98. Wagner S, Hafner C, Allwardt D, Jasinska J, Ferrone S, Zielinski CC, et al. Vaccination with a human high molecular weight melanoma-associated antigen mimotope induces a humoral response inhibiting melanoma cell growth in vitro. J Immunol (2005) 174:976-82. doi:10.4049/jimmunol.174.2.976

99. Luo W, Ko E, Hsu JC, Wang X, Ferrone S. Targeting melanoma cells with human high molecular weight-melanoma associated antigen-specific antibodies elicited by a peptide mimotope: functional effects. J Immunol (2006) 176:6046-54. doi:10.4049/jimmunol.176.10.6046

100. Torisu-Itakura H, Schoellhammer HF, Sim MS, Irie RF, Hausmann S, Raum T, et al. Redirected lysis of human melanoma cells by a MCSP/CD3-bispecific BiTE antibody that engages patient-derived T cells. JImmunother (2011) 34:597-605. doi:10.1097/CJI.0b013e3182307fd8

101. Bluemel C, Hausmann S, Fluhr P, Sriskandarajah M, Stallcup WB, Baeuerle PA, et al. Epitope distance to the target cell membrane and antigen size determine the potency of T cell-mediated lysis by BiTE antibodies specific for a large melanoma surface antigen. Cancer Immunol Immunother (2010) 59:1197-209. doi:10.1007/s00262-010-0844-y

102. McGuirk J, Waller EK, Qayed M, Abhyankar S, Ericson S, Holman P, et al. Building blocks for institutional preparation of CTL019 delivery. Cytotherapy (2017) 19:1015-24. doi:10.1016/j.jcyt.2017.06.001

103. Beard RE, Zheng Z, Lagisetty KH, Burns WR, Tran E, Hewitt SM, et al. Multiple chimeric antigen receptors successfully target chondroitin sulfate proteoglycan 4 in several different cancer histologies and cancer stem cells. J Immunother Cancer (2014) 2:25. doi:10.1186/2051-1426-2-25

104. Geldres C, Savoldo B, Hoyos V, Caruana I, Zhang M, Yvon E, et al. T lymphocytes redirected against the chondroitin sulfate proteoglycan- 4 control the growth of multiple solid tumors both in vitro and in vivo. Clin Cancer Res (2014) 20:962-71. doi:10.1158/1078-0432.CCR-13-2218

105. Craddock JA, Lu A, Bear A, Pule M, Brenner MK, Rooney CM, et al. Enhanced tumor trafficking of GD2 chimeric antigen receptor T cells by expression of the chemokine receptor CCR2b. J Immunother (2010) 33:780-8. doi:10.1097/ CJI.0b013e3181ee6675

106. Larson SM, Carrasquillo JA, Cheung NK, Press OW. Radioimmunotherapy of human tumours. Nat Rev Cancer (2015) 15:347-60. doi:10.1038/ nrc3987

107. Navarro-Teulon I, Lozza C, Pelegrin A, Vives E, Pouget JP. General overview of radioimmunotherapy of solid tumors. Immunotherapy (2013) 5:467-87. doi:10.2217/imt.13.34

108. Allen BJ, Singla AA, Rizvi SM, Graham P, Bruchertseifer F, Apostolidis C, et al. Analysis of patient survival in a phase I trial of systemic targeted alpha-therapy for metastatic melanoma. Immunotherapy (2011) 3:1041-50. doi:10.2217/imt.11.97

109. Kasten B, Fan J, Ferrone S, Zinn K, Buchsbaum D. Targeted radioimmunotherapy of triple negative breast cancer with CSPG4-specific 212Pb-labeled monoclonal antibody. J Nuc Med (2016) 57:114. Available at: http://jnm. snmjournals.org/content/57/supplement_2/114

110. Kreitman RJ. Immunotoxins for targeted cancer therapy. AAPS J (2006) 8:E532-51. doi:10.1208/aapsj080363

111. Akinrinmade OA, Jordaan S, Hristodorov D, Mladenov R, Mungra N, Chetty S, et al. Human MAP Tau based targeted cytolytic fusion proteins. Biomedicines (2017) 5:pii: E36. doi:10.3390/biomedicines5030036 
112. Amoury M, Mladenov R, Nachreiner T, Pham AT, Hristodorov D, Di Fiore S, et al. A novel approach for targeted elimination of CSPG4-positive triple-negative breast cancer cells using a MAP tau-based fusion protein. Int J Cancer (2016) 139:916-27. doi:10.1002/ijc.30119

113. Jordaan S, Chetty S, Mungra N, Koopmans I, van Bommel PE, Helfrich W, et al. CSPG4: a target for selective delivery of human cytolytic fusion proteins and TRAIL. Biomedicines (2017) 5(3):pii: E37. doi:10.3390/biomedicines5030037

114. de Bruyn M, Rybczynska AA, Wei Y, Schwenkert M, Fey GH, Dierckx RA, et al. Melanoma-associated chondroitin sulfate proteoglycan (MCSP)targeted delivery of soluble TRAIL potently inhibits melanoma outgrowth in vitro and in vivo. Mol Cancer (2010) 9:301. doi:10.1186/ 1476-4598-9-301

115. Ilieva KM, Correa I, Josephs DH, Karagiannis P, Egbuniwe IU, Cafferkey MJ, et al. Effects of BRAF mutations and BRAF inhibition on immune responses to melanoma. Mol Cancer Ther (2014) 13:2769-83. doi:10.1158/1535-7163. MCT-14-0290

116. Griffin M, Scotto D, Josephs DH, Mele S, Crescioli S, Bax HJ, et al. BRAF inhibitors: resistance and the promise of combination treatments for melanoma. Oncotarget (2017) 8(44):78174-92. doi:10.18632/oncotarget.19836

117. PucciarelliD,LenggerN,TakacovaM,CsaderovaL,BartosovaM,BreitenederH, et al. Anti-chondroitin sulfate proteoglycan 4-specific antibodies modify the effects of vemurafenib on melanoma cells differentially in normoxia and hypoxia. Int J Oncol (2015) 47:81-90. doi:10.3892/ijo.2015.3010
118. Amoury M, Bauerschlag D, Zeppernick F, von Felbert V, Berges N, Di Fiore S, et al. Photoimmunotheranostic agents for triple-negative breast cancer diagnosis and therapy that can be activated on demand. Oncotarget (2016) 7:54925-36. doi:10.18632/oncotarget.10705

119. Burns WR, Zhao Y, Frankel TL, Hinrichs CS, Zheng Z, Xu H, et al. A high molecular weight melanoma-associated antigen-specific chimeric antigen receptor redirects lymphocytes to target human melanomas. Cancer Res (2010) 70:3027-33. doi:10.1158/0008-5472.CAN-09-2824

120. Inacio R, Poland S, Cai XJ, Cleary SJ, Ameer-Beg S, Keeble J, et al. The application of local hypobaric pressure - a novel means to enhance macromolecule entry into the skin. J Control Release (2016) 226:66-76. doi:10.1016/j. jconrel.2016.01.052

Conflict of Interest Statement: SK and JS are founders and shareholders of IGEM Therapeutics Ltd. All other authors declare no conflicts of interest.

Copyright (c) 2018 Ilieva, Cheung, Mele, Chiaruttini, Crescioli, Griffin, Nakamura, Spicer, Tsoka, Lacy, Tutt and Karagiannis. This is an open-access article distributed under the terms of the Creative Commons Attribution License (CC BY). The use, distribution or reproduction in other forums is permitted, provided the original author(s) or licensor are credited and that the original publication in this journal is cited, in accordance with accepted academic practice. No use, distribution or reproduction is permitted which does not comply with these terms. 